Article

\title{
Transport and Deposition of Microplastics and Mesoplastics along the River Course: A Case Study of a Small River in Central Italy
}

\author{
Luca Gallitelli ${ }^{1}$, Giulia Cesarini ${ }^{1}{ }^{1}$, Alessandra Cera ${ }^{1, *}$, , Maria Sighicelli ${ }^{2}$, Francesca Lecce ${ }^{2}$, \\ Patrizia Menegoni ${ }^{2}$ and Massimiliano Scalici ${ }^{1}$ \\ 1 Department of Sciences, University of Roma Tre, Viale G. Marconi 446, 00146 Rome, Italy; \\ luca.gallitelli@hotmail.it (L.G.); giulia.cesarini@uniroma3.it (G.C.); massimiliano.scalici@uniroma3.it (M.S.) \\ 2 ENEA, CR Casaccia, Via Anguillarese, 301, 00123 Rome, Italy; maria.sighicelli@enea.it (M.S.); \\ francesca.lecce@enea.it (F.L.); patrizia.menegoni@enea.it (P.M.) \\ * Correspondence: alessandra.cera@uniroma3.it
}

Received: 29 October 2020; Accepted: 16 November 2020; Published: 18 November 2020

\begin{abstract}
The release of plastics in freshwater is an increasing concern for ecosystem safety worldwide. There is a large knowledge gap on plastic pollution in Mediterranean freshwater, especially regarding surveys along entire river courses, partly due to the absence of guidelines for standardized monitoring of plastics. The present study analyzes the plastic distribution from source to mouth, also according to the River Continuum Concept, of the environmental matrices (water and sediments) and biota (caddisfly cases) of the Mediterranean River Mignone and their cause-effect relationship. The results of the water quality indices (Extended Biotic Index and Fluvial Functionality Index) were compared with the plastic concentrations observed in the water and sediments to explore what relationship there might be and to understand if the indices could be a proxy of the plastic pollution. Our results showed a significant prevalence of blue fibers, the concentration of which in water and sediment is positively associated. Plastic concentration at each site was not accurately detected by the water quality indices. These results may suggest that the factors considered by water quality indices are not able to detect the contamination of plastic pollution. It is mandatory to identify new tools for assessing the plastic impacts on river ecosystems.
\end{abstract}

Keywords: Mediterranean rivers; freshwater; grain size analysis; plastic; microplastic; mesoplastic; macroinvertebrates; case construction; Extended Biotic Index; monitoring; Fluvial Functionality Index

\section{Introduction}

Plastic is a growing concern as it contaminates aquatic ecosystems due to human activities, such as improper waste management and accidental loss, causing several negative effects on biota $[1,2]$. The mismanagement of plastic litter allows for contamination of freshwater ecosystems globally [3,4]. Indeed, water samples from 168 rivers around the world were analyzed, showing a contamination mean value of 11,128 items $\mathrm{m}^{-3}$, while regarding sediment, 96 rivers analyzed provide a mean value of 1161 items kg-1 [4]. However, the contamination of rivers varies between the sampling sites, ranging from values close to zero to thousands of items per unit [4]. In particular, we focus on the rivers flowing into the Mediterranean Sea that are contaminated but understudied (Table 1). 
Table 1. Plastic concentration for water and sediment of rivers flowing into the Mediterranean Sea.

\begin{tabular}{cccc}
\hline Matrix & Plastic Concentration & Study Area & Reference \\
\hline Water & $1-84$ items $/ \mathrm{m}^{3}$ & River Po mouth (Italy) & Atwood et al., 2019 [5] \\
& $0.5-18$ items $/ \mathrm{m}^{3}$ & Ofanto River (Italy) & Campanale et al., 2020 [6] \\
& $2.4-88.4$ items $/ \mathrm{m}^{3}$ & Rhône River (France) & Constant et al., 2020 [7] \\
& $0.8-618$ items $/ \mathrm{m}^{3}$ & Têt River (France) & Constant et al., 2020 [7] \\
& $2.1-4.9$ items $/ \mathrm{m}^{3}$ & Ebro River delta (Spain) & Simon-Sánchez et al., 2019 [8] \\
Sediment & $72-191$ items $/ \mathrm{kg}$ & Cecina River estuary (Italy) & Blašković et al., 2018 [9] \\
& $33-798$ items $/ \mathrm{kg}$ & Têt River (France) & Constant et al., 2020 [7] \\
& $45-1069$ items $/ \mathrm{kg}$ & Ombrone River (Italy) & Guerranti et al., 2017 [10] \\
& $1306-2798$ items $/ \mathrm{kg}$ & Ebro River delta (Spain) & Simon-Sánchez et al., 2019 [8] \\
\hline
\end{tabular}

Although the effects of plastic on freshwater biota are documented [11], it is difficult to identify sources in order to reduce contamination $[12,13]$. Regarding point source pollution, several studies highlighted possible sources of plastic pollution, especially wastewater treatment plants $[14,15]$ and agriculture [6]. Indeed, areas with wastewater treatment plants are linked to a greater presence of plastic fibers $[14,15]$. Fibers are one of the most common plastic pollutants and are connected to the release of synthetic clothes fibers from washing machines [16].

In particular, several studies found that synthetic plastic fibers can be found in samples from water, sediments, and biota, and can accumulate in the environment [17]. For instance, large quantities of fibers were found in the River Seine [18]. Fibers can be transported as airborne particles or accumulate in the sewage treatment plant and then can be available in the environment, as bacteria cannot quickly decompose them $[16,18]$. The fate and transport of microplastic fibers from washing machine to the sea is affected by wastewater treatment plants. After their release, microfibers pass into domestic drainages and enter the oceans via wastewater treatment plants and rivers [16]. Sewage treatment is an important factor affecting microplastic fibers pollution. Indeed, fibers were found in effluent from sewage treatment plants. Hence, effluent discharge often contains microfibers, which are not removed during the treatment process, and this increases the availability of microplastics fibers in situ [16].

Concerning the models used to investigate the distribution of plastics, cluster analysis was used as a tool in order to find the source of plastics by considering their characteristics (such as color, size and shape) at different sampling sites [19]. Several studies highlighted how different factors (e.g., particle size, river hydrodynamics) could influence the distribution of plastic in the river substrate $[12,20]$. In particular, the deposition of plastic in rivers follows the same pattern as natural particles [21], and river flow is a crucial factor affecting the behavior of both natural particles and plastics during transport and sedimentation. After settling, a strong flow can remobilize plastic items such as during sediment erosion $[20,22,23]$. Indeed, rivers change from being sinks to sources of plastics under flood conditions [23]. Further investigations are needed to better understand the factors influencing the plastic contamination pattern to manage and preserve the riverine ecosystems.

As plastics have an increasing impact on global riverine ecosystems and assessing their water quality is mandatory, the existing quality indices could provide information on plastic contamination. The water quality indices regulated by European Directive 2000/60/EC (i.e., Water Framework Directive, WFD) [24], require the use of biological indicators such as fish, diatoms, macrophytes and macroinvertebrates to evaluate the status (from very bad to excellent) of aquatic ecosystems. In particular, the occurrence of specific taxa of the macroinvertebrate community is an excellent tool to provide results for the assessment of water quality due to the different degree of sensitivity to changes in environmental factors, such as dissolved oxygen, $\mathrm{pH}$, temperature and water transparency. For example, some taxa (i.e., Ephemeroptera, Plecopera and Trichoptera) occur more in good-quality waters, while other taxa (e.g., Chironomidae, Simuliidae, Gammaridae) are more tolerant and are found even in low-quality waters. Although macroinvertebrates are widely used in monitoring activities according to the WFD, the suitability of macroinvertebrate indices to detect plastic contamination is still poorly investigated $[25,26]$. Indeed, it is unknown whether the presence of plastics in rivers 
can affect the occurrence of the macroinvertebrate community, therefore influencing the results of water quality indices based on macroinvertebrates, such as the Standardization of River Classifications Intercalibration Common Metric index (STAR_ICMi) [24] and Extended Biotic Index (EBI) [27].

In addition to the biological indices, there is a method for the assessment of environmental status of a watercourse: The Fluvial Functionality Index (FFI) [28]. The FFI considers all the hydro-morphological elements cited in the WFD and allows to evaluate the overall quality state of the river ecosystem in relation to its functionality, i.e., the buffer function performed by the riparian ecotone, the morphological structure of the riverbed, the ability of banks and the entire course of the river to provide shelter and a suitable habitat for different biological communities. Therefore, the watercourse is observed throughout its entire course by analyzing its abiotic (morphological and structural) and biotic components (riverbed, riparian and periphery vegetation, macroinvertebrates and fish). The FFI allows identifying sections of a watercourse with a high ecological value and the impacted ones, highlighting their functional criticality and classifying its functionality [28]. However, even in this case, the suitability of the FFI to reveal disturbances induced by plastic contamination has not yet been evaluated to our knowledge.

This study aimed to investigate (i) the association between plastics and sediments according to river dynamism, and (ii) whether the water quality index based on macroinvertebrates community assessment EBI and the ecosystem functionality index FFI can be a proxy of plastic concentration in water and sediments.

\section{Materials and Methods}

\subsection{Study Area}

This study was conducted in River Mignone (Latium, Italy) by sampling water, sediments and macroinvertebrates in nine sites (S1-S9) (Table 2), distributed from source (S1) to mouth (S9) (Figure 1) during July 2018. In the upper (S1, S2) and medium (S3-S5) course, Mignone has well-conserved freshwater ecosystems, which are preserved by two European protected areas (i.e., Sites of Community Interest, Site Code: IT6010033 and IT6030001). However, some threats affect the Mignone catchment, e.g., sewage discharges of urban centers and agricultural lands [29,30]. The lower course (S6-S9) indirectly received sewage from other towns and agricultural lands in the catchment area.

Table 2. Global Positioning System (GPS) coordinates of the stations on River Mignone sampled for water, sediments and macroinvertebrates during July 2018.

\begin{tabular}{cccc}
\hline Sampling Site & Station Label & Latitude & Longitude \\
\hline Vejano & $\mathrm{S} 1$ & $42^{\circ} 12^{\prime} 36.82^{\prime \prime} \mathrm{N}$ & $12^{\circ} 5^{\prime} 39.02^{\prime \prime} \mathrm{E}$ \\
Mola di Oriolo & $\mathrm{S} 2$ & $42^{\circ} 10^{\prime} 16.81^{\prime \prime} \mathrm{N}$ & $12^{\circ} 5^{\prime} 35.24^{\prime \prime} \mathrm{E}$ \\
Canale Monterano & $\mathrm{S} 3$ & $42^{\circ} 7^{\prime} 58.09^{\prime \prime} \mathrm{N}$ & $12^{\circ} 3^{\prime} 12.13^{\prime \prime} \mathrm{E}$ \\
Rota & $\mathrm{S} 4$ & $42^{\circ} 9^{\prime} 13.69^{\prime \prime} \mathrm{N}$ & $12^{\circ} 0^{\prime} 34.98^{\prime \prime} \mathrm{E}$ \\
Monte Romano & $\mathrm{S} 5$ & $42^{\circ} 13^{\prime} 30.07^{\prime \prime} \mathrm{N}$ & $11^{\circ} 55^{\prime} 50.29^{\prime \prime} \mathrm{E}$ \\
Casale Santa Maria & $\mathrm{S} 6$ & $42^{\circ} 13^{\prime} 52.36^{\prime \prime} \mathrm{N}$ & $11^{\circ} 53^{\prime} 42.10^{\prime \prime} \mathrm{E}$ \\
La Farnesiana & $\mathrm{S} 7$ & $42^{\circ} 13^{\prime} 5.43^{\prime \prime} \mathrm{N}$ & $11^{\circ} 50^{\prime} 34.27^{\prime \prime} \mathrm{E}$ \\
Fontana Matta & $\mathrm{S} 8$ & $42^{\circ} 11^{\prime} 44.79^{\prime \prime} \mathrm{N}$ & $11^{\circ} 47^{\prime} 32.91^{\prime \prime} \mathrm{E}$ \\
Foce & $\mathrm{S} 9$ & $42^{\circ} 10^{\prime} 35.36^{\prime \prime} \mathrm{N}$ & $11^{\circ} 44^{\prime} 7.25^{\prime \prime} \mathrm{E}$ \\
\hline
\end{tabular}




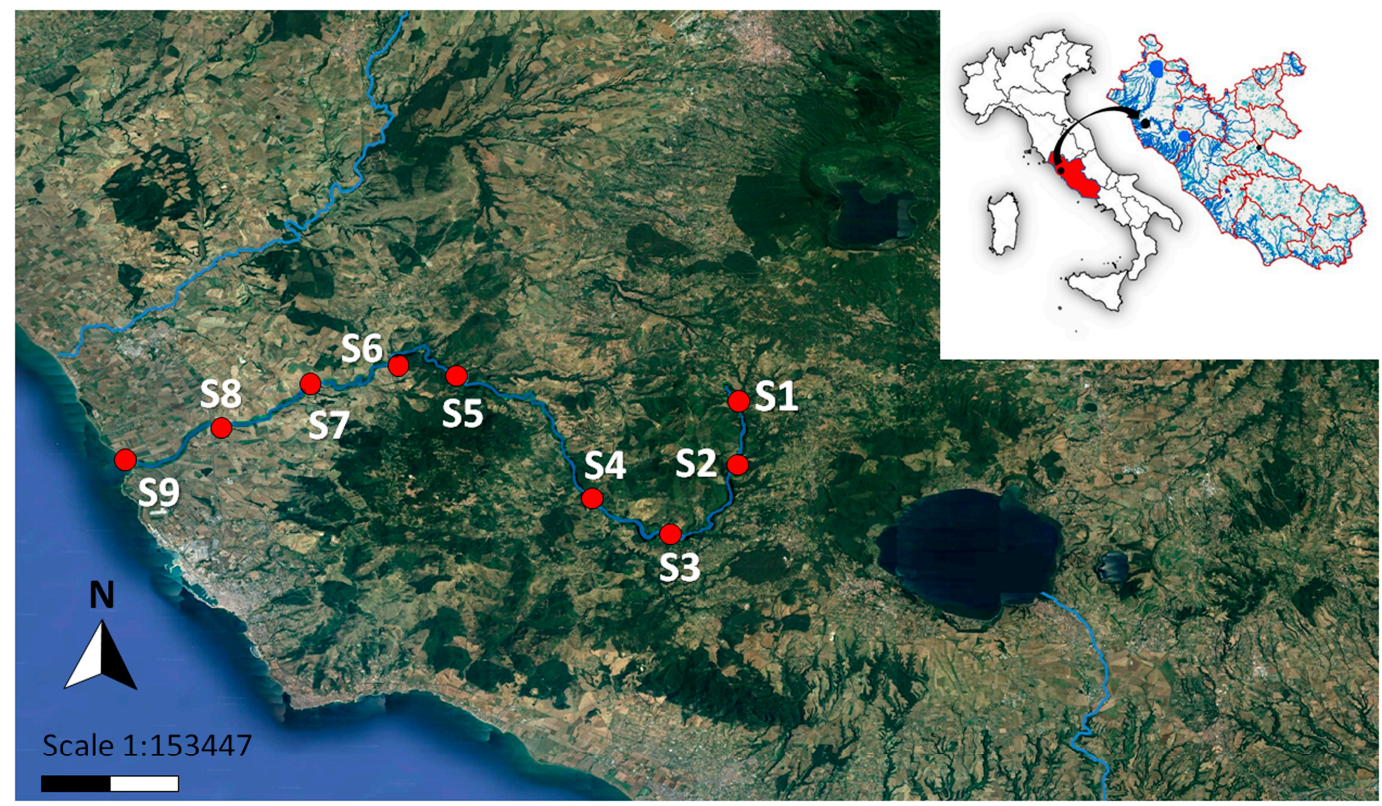

Figure 1. The sampling sites of water, sediments and macroinvertebrates along the River Mignone are highlighted from site 1 (S1), located near the source, to site 9 (S9), located near the mouth (image processed by QGIS ver. 3.12.2).

\subsection{Sampling of Water, Sediments and Macroinvertebrates}

In each sampling site, the water was sampled by a plankton net with a mesh size of $80 \mu \mathrm{m}$ and a diameter of $13 \mathrm{~cm}$. Water velocity $\left(\mathrm{cm} \mathrm{s}^{-1}\right)$ was measured by flowmeter General Oceanics 2030 series [31]. The net was held against the current in the middle of the river $13 \mathrm{~cm}$ below the water surface for maximum 1 min (Supplementary Figure S1). The net was rinsed with distilled water to detach the items attached to the net itself. The filtered water sample $(100 \mathrm{~mL})$ was stored in sterilized falcons.

Regarding sediments, 12 samples were collected from each of the nine sampling sites following a linear transept connecting the opposite banks of the river. Three samples were collected from the left riverbank, six samples from the riverbed and three samples from the right riverbank (Figure 2). For each sample, approximately $250 \mathrm{~mL}$ of sediment was taken from the upper layer of the substrate ( $5 \mathrm{~cm}$ deep) by metal tools and was stored in $250 \mathrm{~mL}$ sterilized aluminum containers.

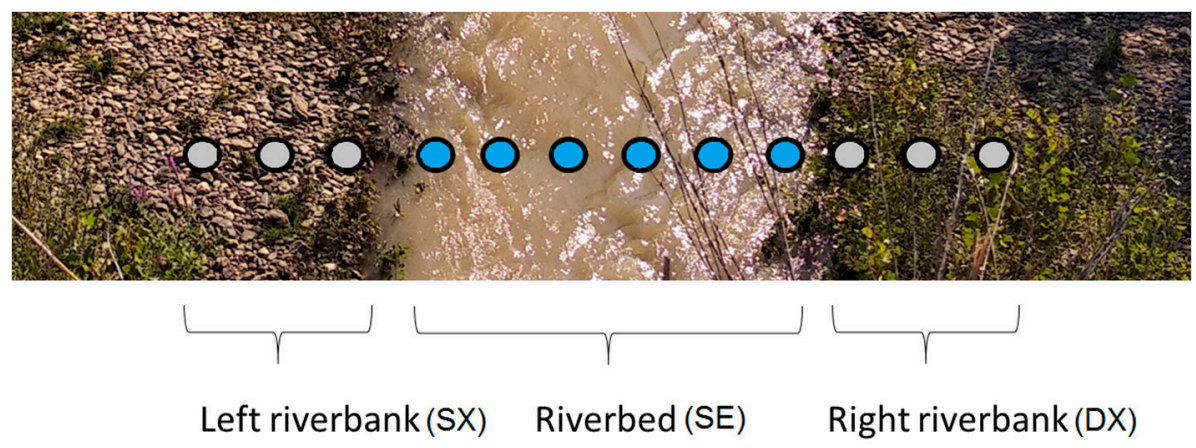

Figure 2. Sediment sampling in each station following a linear transept: 3 samples on the left riverbank (SX) represented in grey, 6 samples on the riverbed (SE) represented in blue and 3 samples on the right riverbank (DX) represented in grey.

Macroinvertebrates were sampled along a linear transect parallel to the banks, following the procedure of kick sampling used for the EBI, trying to consider all possible habitats present in the 
sampling site. Then, macroinvertebrates were stored in alcohol $(70 \%)$ and transported to the laboratory for identification to the lowest possible taxa [32].

\subsection{Visual Detection of Plastics in Water, Sediments and Macroinvertebrates}

A pre-treatment consisting of $30 \% \mathrm{H}_{2} \mathrm{O}_{2}$ (30 volume) added to each water sample was conducted to digest biological matter [33]. Then, the digested water sample was observed under a stereomicroscope (LEICA EZ4HD) to pick plastic items $>1 \mathrm{~mm}$. The number of plastic items per volume of filtered water is reported as items $\mathrm{m}^{-3}$ in each station, according to scientific literature $[4,5,18]$.

Sediments samples were dried in a laboratory stove (Salvis Lab TC160) at $60{ }^{\circ} \mathrm{C}$ for $48 \mathrm{~h}$. Once dried, each sample was divided into subsamples according to their grain size by a vibrator sieve (Retsch basic AS200) and each subsample was weighed (WTB 2000 Radwag balance). The sediment subsamples $>1 \mathrm{~mm}$ were placed in aluminum containers to form a layer of a few millimeters, facilitating the sample sorting. Then, the subsamples were observed by a stereomicroscope (LEICA EZ4HD) to pick plastic items using metal stainless forceps. The number of particles found in the substrate is reported in items $\mathrm{kg}^{-1}$, according to recent studies [4,8,34]. In addition, the results of grain size analysis are provided. Specifically, the coarse fraction $(>100 \mu \mathrm{m})$ is divided by dry sieving to obtain the grain size, as described above. The resulting distribution is analyzed by SEDPLOT software and the Folk classification scheme $[35,36]$.

Regarding macroinvertebrates, the presence of plastic items in the cases of sampled caddisflies was checked, based on recent observations in scientific literature [37-39]. Cases were digested in a solution containing $30 \% \mathrm{H}_{2} \mathrm{O}_{2}$ (30 volume) at $37{ }^{\circ} \mathrm{C}$ for $48 \mathrm{~h}$ (adapted from Nuelle et al.) [33,38]. Thereafter, the digested cases were observed by a stereomicroscope (Nikon C-LEDS, China) to identify the plastics.

For all three matrices, plastic items were classified according to their color and shape [39], such as fibers, fragments and films [40-42]. In addition, the color of plastic items in water was analyzed on a randomly chosen subsample of 52 items, while of 25 items for plastic in sediments. Concerning biota, the entire sample was analyzed.

Laboratory coats and steel tools were used by the research team during all laboratory activities to avoid contamination.

\subsection{Fourier Transform Infrared Spectroscopy (FT-IR) Analysis and Polymer Identification}

Fourier Transform Infrared spectroscopy (FT-IR) was applied for polymer identification of 77 plastic particles randomly selected ( $34 \%$ of total items). FT-IR spectra were collected in attenuated total reflectance (ATR) mode using a Thermo Scientific Nicolet iS5 6700 spectrophotometer: spectrum range was $4000-400 \mathrm{~cm}^{-1}$ and the resolution was $4 \mathrm{~cm}^{-1}$. Chemical composition of polymer particles was identified by comparison with the reference spectra database (instrument library). The identification was accepted with a threshold $r>0.90$ as a value of similarity among samples

\subsection{Quality Indices}

The ecological quality status of River Mignone was analyzed by the diversity of macroinvertebrates taxa found, according to the EBI [27], and by the survey of river environmental status, according to the FFI [28].

Regarding the calculation of the EBI, the identification of sampled macroinvertebrates to the lowest taxa allows collecting two types of information to be inserted in a double-entry matrix: (1) the taxa occurring at each site and (2) the richness of the taxa found. The intersection between the two types of information yields a score that corresponds to one out of five water quality classes, going from "very bad" (score 0-3, class V) to "excellent" (score 10-14, class I).

Concerning the FFI, the index is structured as 14 questions about the vegetative condition of the banks and the territory surrounding watercourse, relative width of the wet riverbed and morpho-physical structure of the banks, structure of the riverbed and biological characteristics. 
Every question is repeated for each bank (left and right) and the answer is evaluated, assigning a score ranging from 1 to 30 . The overall score is translated into a "level of functionality", which can go from "very bad" (for FFI scores below 51) to "excellent" (for FFI scores above 260). As regards the fish data, we considered recent scientific literature data on fish occurrence in River Mignone [43].

\subsection{Statistical Analyses}

All statistical analyses were performed by Statistica software (ver. 10). Before the analyses, normality of data was checked by the Shapiro-Wilk test. If distribution was not normal, non-parametric tests were used. The different abundance between the shapes of plastics is tested by the Kruskal-Wallis test for water and sediment stations along the river course. Specifically, on sediments, a t-test was conducted to test the difference between the concentration of plastics in sediments of riverbed and riverbanks, and a Kruskal-Wallis test was used to separately test the difference between the concentration of plastics in the sediments of riverbed and two riverbanks (left and right). To compare the concentrations of plastic in water and riverbed sediments, the units of measurement items $\mathrm{l}^{-1}$ are homologated in items $\mathrm{kg}^{-1}$, following the assumptions reported in Cera et al. [4].

A Kruskal-Wallis test was performed to assess whether there is a difference between the concentration of plastic types in water and sediments of the three zones of the river identified by the River Continuum Concept (RCC), described as follows. According to the RCC [44], an ecological gradient is formed along the river course going from source to mouth, based on the variation of abiotic and biotic factors. Therefore, rivers can be divided into three zones: crenal, rhithral and potamal [45]. Hence, the sampling sites of River Mignone were divided into the three zones: (1) S1 and S2 are part of crenal, (2) S3-S5 of rhithral, and (3) S7-S9 of potamal. This categorization was carried out leaving out station $\mathrm{S} 6$ because it is located in a transition zone between rhithral and potamal, and thus it does not fit precisely into one of the three zones previously defined.

In addition, to investigate the trend of plastic concentration along the river course, Spearman's correlation test was used to investigate the association between concentration of plastics in water, sediments and biota along the entire river course. According to those results, a linear regression was tested for the concentrations of plastic fibers in water and riverbed sediments. For these analyses, riverbank and riverbed sediment samples are analyzed separately as their plastic concentrations are not correlated. Moreover, a linear regression was calculated between the distance $(\mathrm{km})$ of stations from the river source and the concentration of plastics in water and sediments.

As regards biotic and environmental indices, Pearson's correlation test was used to investigate the association between plastic concentration in water and riverbed sediments and the results of EBI and FFI.

\section{Results}

\subsection{Quantitative and Qualitative Description of Plastics in River Mignone}

The total amount of plastic items found in water and sediments of River Mignone were 214 (148 and 66, respectively), of which 75\% were fibers, $18 \%$ fragments and $7 \%$ films. The concentration of fibers is more abundant than films in water and sediments (water: $\mathrm{H}=7.448, \mathrm{df}=4, p<0.05$, sediment: $\mathrm{H}=6.489, \mathrm{df}=4, p<0.05$ ) (Figure 3a; Supplementary Table S1), while there is no significant difference with fragments. Sediments have a higher concentration of plastics than water, as the mean concentrations of plastics found are 1.32 and 0.28 items $\mathrm{kg}^{-1}$, respectively (Figure 4). In addition, 42 plastic items were found in biota, all fibers (Figure 3a; Supplementary Table S1). 


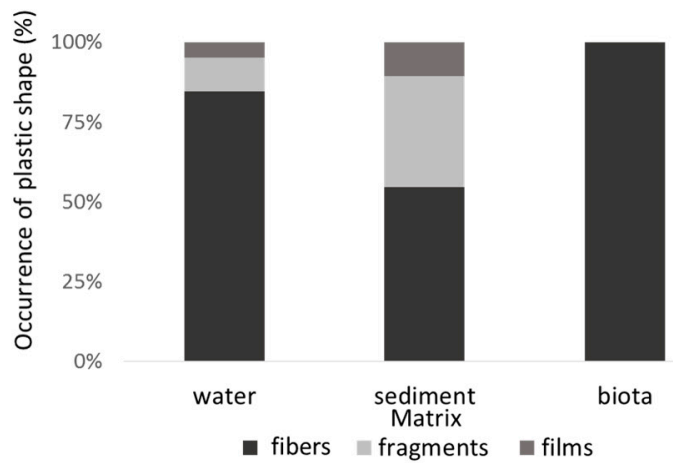

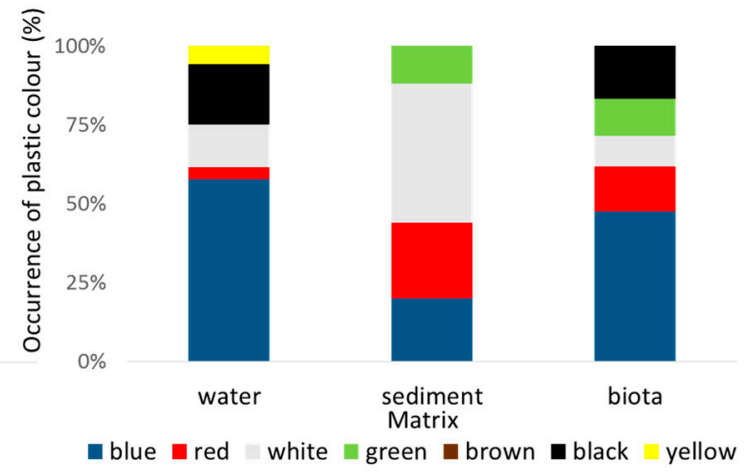

b

Figure 3. (a) Frequency of plastic shapes in water, sediment and biota (caddisfly cases), (b) frequency of colors in water, sediment and biota (caddisfly cases).

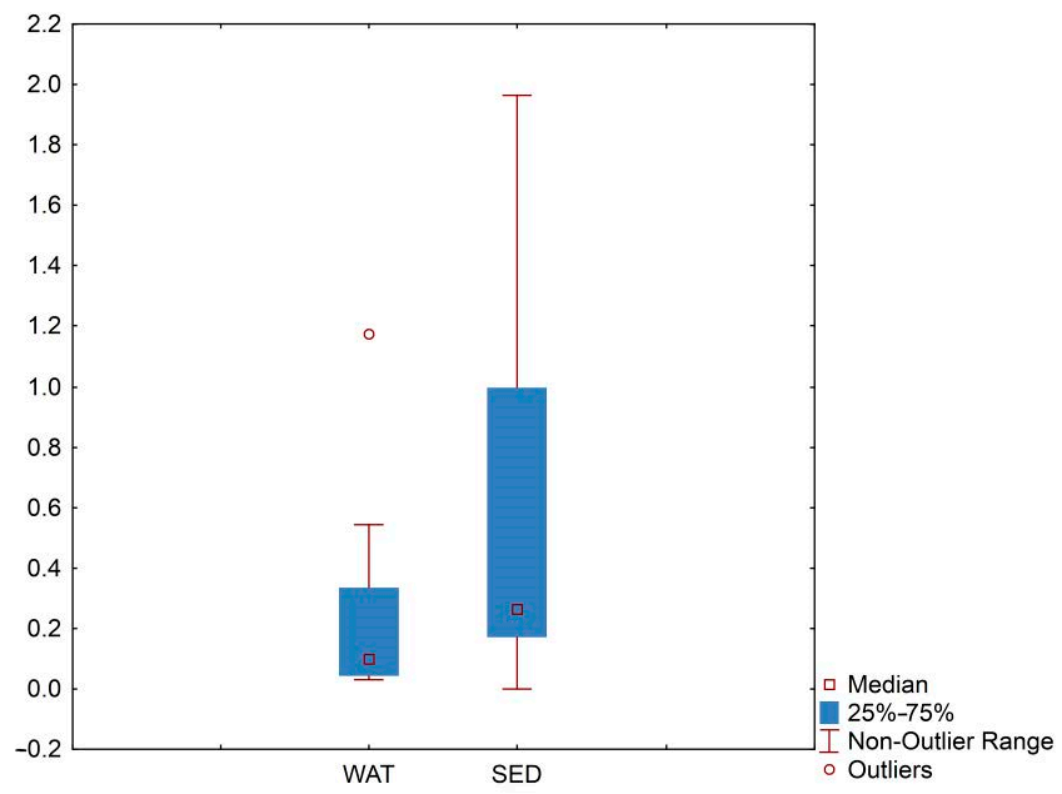

Figure 4. Boxplot comparing the concentration of plastic items found in water and riverbed sediments.

\subsubsection{Plastic Items in Water}

All 148 plastic items collected from water were between the size of 1 and $5 \mathrm{~mm}$ (i.e., large microplastic). The mean concentration of plastic was 0.28 items $\mathrm{L}^{-1}$, while the range of plastic concentration was $0.03-1.17$ items $\mathrm{L}^{-1}$ (Table 3). Fibers represented $84.5 \%$, while fragments represented $10.8 \%$ and films $4.7 \%$ (Figure 3a). Blue was the color mostly observed visually (58\%), followed by black (19\%), white (14\%), yellow (6\%) and red (4\%) (Figure 3b). The chemical composition of the microplastic particles examined by FT-IR clearly shows the dominant presence of polyethylene (PE) with 50\% occurrence.

Table 3. Plastic concentration in water, sediments and caddisfly cases along River Mignone.

\begin{tabular}{|c|c|c|c|c|c|c|}
\hline \multirow{3}{*}{ Station } & \multirow{3}{*}{$\begin{array}{c}\text { Plastic } \\
\text { Concentration } \\
\text { in Water } \\
\left(\text { Items L }{ }^{-1}\right)\end{array}$} & \multicolumn{4}{|c|}{ Plastic Concentration in Sediment (Items $\mathrm{Kg}^{-1}$ ) } & \multirow{3}{*}{$\begin{array}{c}\text { Mean Number of } \\
\text { Plastic Items in } \\
\text { Caddisfly Cases } \\
\text { (Items Case }^{-1} \text { ) }\end{array}$} \\
\hline & & \multirow{2}{*}{ Total } & \multirow{2}{*}{ Riverbed } & \multicolumn{2}{|c|}{ Riverbank } & \\
\hline & & & & Left & Right & \\
\hline S1 & 0.04 & 0.2987 & 0 & 0 & 0.2987 & n.a. ${ }^{1}$ \\
\hline S2 & 0.04 & 2.4543 & 1.9634 & 0.1636 & 0.3272 & n.a. ${ }^{1}$ \\
\hline S3 & 0.03 & not sampled & not sampled & not sampled & not sampled & n.a. ${ }^{1}$ \\
\hline
\end{tabular}


Table 3. Cont.

\begin{tabular}{|c|c|c|c|c|c|c|}
\hline \multirow{3}{*}{ Station } & \multirow{3}{*}{$\begin{array}{c}\text { Plastic } \\
\text { Concentration } \\
\text { in Water } \\
\left(\text { Items } L^{-1} \text { ) }\right.\end{array}$} & \multicolumn{4}{|c|}{ Plastic Concentration in Sediment (Items $\mathrm{Kg}^{-1}$ ) } & \multirow{3}{*}{$\begin{array}{l}\text { Mean Number of } \\
\text { Plastic Items in } \\
\text { Caddisfly Cases } \\
\text { (Items Case }^{-1} \text { ) }\end{array}$} \\
\hline & & \multirow{2}{*}{ Total } & \multirow{2}{*}{ Riverbed } & \multicolumn{2}{|c|}{ Riverbank } & \\
\hline & & & & Left & Right & \\
\hline S4 & 0.10 & 2.3815 & 1.4743 & 0.0000 & 0.9072 & 7.5 \\
\hline S5 & 0.07 & 0.9977 & 0.9977 & 0.0000 & 0 & 16 \\
\hline S6 & 0.34 & 1.0322 & 0.1720 & 0.1720 & 0.6881 & 1.0 \\
\hline S7 & 0.21 & 1.5868 & 0.2645 & 0.7934 & 0.5289 & n.a. ${ }^{1}$ \\
\hline S8 & 0.54 & 0.9395 & 0.2349 & 0.0000 & 0.7046 & 1.0 \\
\hline S9 & 1.17 & 0.7779 & 0.6483 & 0.1297 & 0 & n.a. ${ }^{1}$ \\
\hline mean & 0.28 & 1.3086 & 0.7194 & 0.1573 & 0.4319 & 6.4 \\
\hline total & 2.54 & 10.4687 & 5.7551 & 1.2587 & 3.4549 & 25.5 \\
\hline
\end{tabular}

${ }^{1}$ data not available because no caddisfly case was found.

\subsubsection{Plastic Items in Sediments}

As grain size analysis showed, sediments are mostly sandy gravel (Figure 5; Supplementary Table S2). Moreover, 66 plastic items were found in sediment samples. In particular, 9 items ranged between the size of 5 and $10 \mathrm{~mm}$ (i.e., mesoplastics), while 57 were between 1 and $5 \mathrm{~mm}$ (i.e., large microplastics). The mean concentration of plastic was 1.16 items $\mathrm{kg}^{-1}$, while the range of plastic concentration was $0-2.45$ items kg-1 (Table 3). Most of the plastic items were fibers (54.5\%), followed by fragments (34.8\%) and films (10.6\%) (Figure 3a). The most frequent colors were white $(44 \%)$ and red $(24 \%)$, followed by blue $(20 \%)$, green $(8 \%)$ and brown ( $4 \%$; Figure $3 \mathrm{~b})$. Polymer type composition showed the dominant occurrence of $\mathrm{PE}$, polypropylene (PP) and polyamide (PA), with mean frequency of $40 \%, 16 \%$ and $14 \%$, respectively (Supplementary Figure S2). Few particles were identified as polyester, with 7\% occurrence.

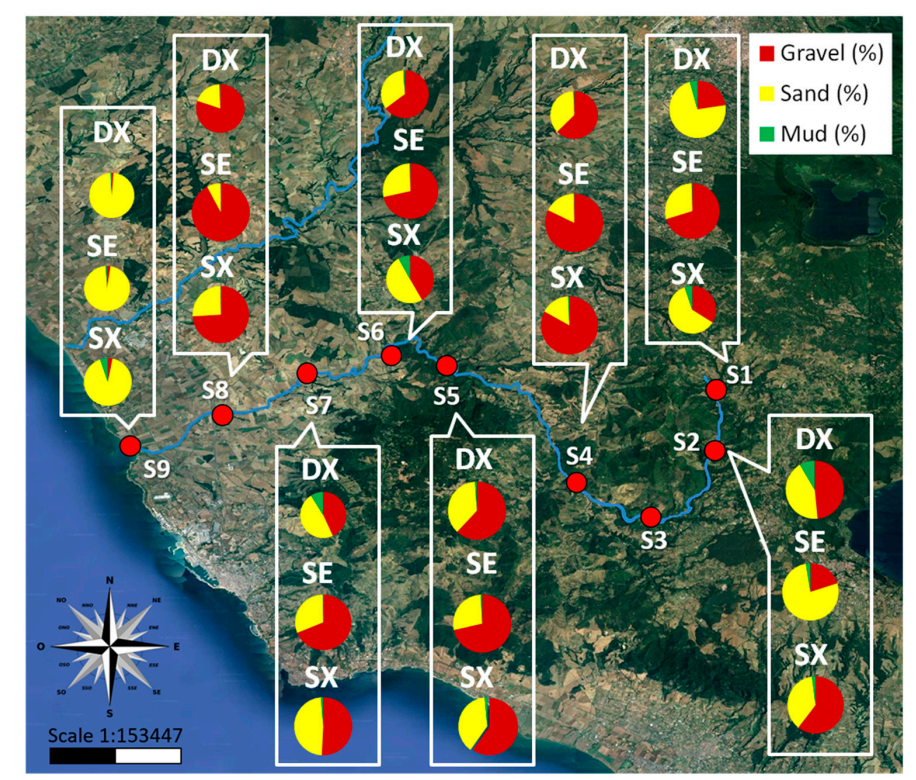

Figure 5. Frequency of grain size sediment for each station divided for riverbed (SE), left riverbank (SX) and right riverbank (DX). Gravel: particles $>2 \mathrm{~mm}$, sand: $0.063 \mathrm{~mm}<$ particles $<2 \mathrm{~mm}$, mud: particles $<0.063 \mathrm{~mm}$.

Our monitoring activities revealed that the number of plastic items occurred mostly in the sediments of the riverbed (61\%), followed by the right riverbank (30\%), and lastly, by the left riverbank $(9 \%)$. However, there was not a significant difference between the plastic concentration in riverbed and riverbank sediments and not even between right and left riverbank sediments. 


\subsubsection{Plastic Items in Macroinvertebrates}

In 14 caddisfly cases belonging to Bereidae and Hydroptilidae families sampled in four stations (S4, S5, S6 and S8), 42 plastic items were observed (Figure 6). The mean number of plastic items of all cases found at each station is shown in Table 3. The mean concentration of plastic was 6.4 items for case (Table 3). All the plastic items were $<5 \mathrm{~mm}$ (i.e., small and large microplastics) and belonged to fibers, of which $48 \%$ were blue (Figure 3). A minor number of items were black $(17 \%)$, red $(14 \%)$, green $(12 \%)$ and white $(9 \%)$.

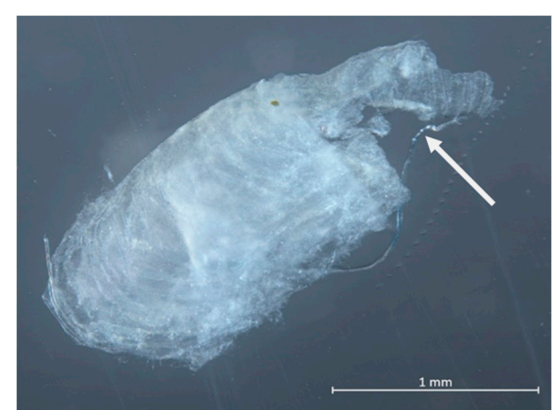

Figure 6. Hydroptilidae caddisfly case with a white fiber of plastic indicated by the white arrow. Photo by Dr. Silvio Kroha; Microscope ZEISS Axio Zoom.V16 connected to an Axiocam 503 (Stereo Zoom Microscope).

\subsection{Analysis of the Distribution of Plastics}

The concentration of plastics varied among the stations (Table 3), however, the distance from the river source significantly affected the plastic concentration in water $\left(y=0.01857 x-0.1369, R^{2}=0.57\right.$, $\mathrm{F}(1,7)=9.2721, p<0.019$ ) but not in sediments (Figure 7). Plastic concentration is not significantly different among the three river zones of River Mignone, divided according to the RCC.
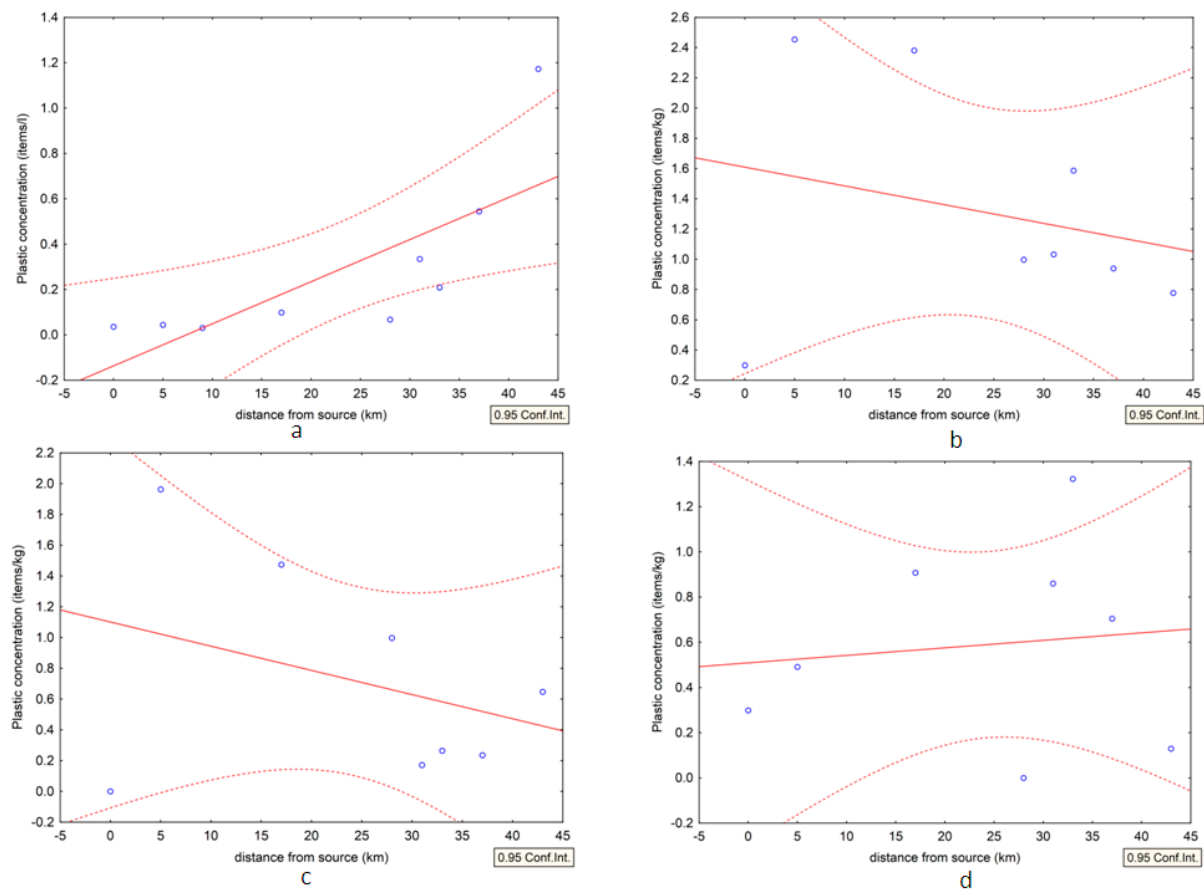

Figure 7. Scatter plot of the distance from the river source in each station and the concentration of plastics in: (a) water, (b) total sediments, (c) sediments of the riverbed and (d) sediments of the riverbanks. Dotted lines indicate the confidence interval, the continuous line indicate the regression line. 
There was a non-significant association between the concentration of plastics in water, sediments and biota. Similarly, the correlation between the plastic types (fibers, fragments and films) in water and in sediments (both riverbed and riverbanks) were not significantly correlated.

\subsection{Comparison between the Results of Plastic Occurrence and Quality Indices}

For EBI, S5 and S7 had excellent water quality, showing higher EBI scores than other stations (Figure 8). Concerning the other stations, S1, S2, S4 and S8 showed good water quality, while S3 and S6 had sufficient water quality. The lowest water quality (bad) was found at the riverine mouth (S9). Most sites have good water quality (44\%), corresponding to class II (Figure 8 ).

Regarding the FFI, excellent scores were found in S1 and S5, while bad scores were found in S9 (Figure 8). Most sites had a sufficient level of fluvial functionality (44\%) or higher (i.e., good or excellent levels in $44 \%$ of sites).

Plastic concentration was not significantly correlated to EBI and FFI indices both in water and in sediment (Figure 9).

a
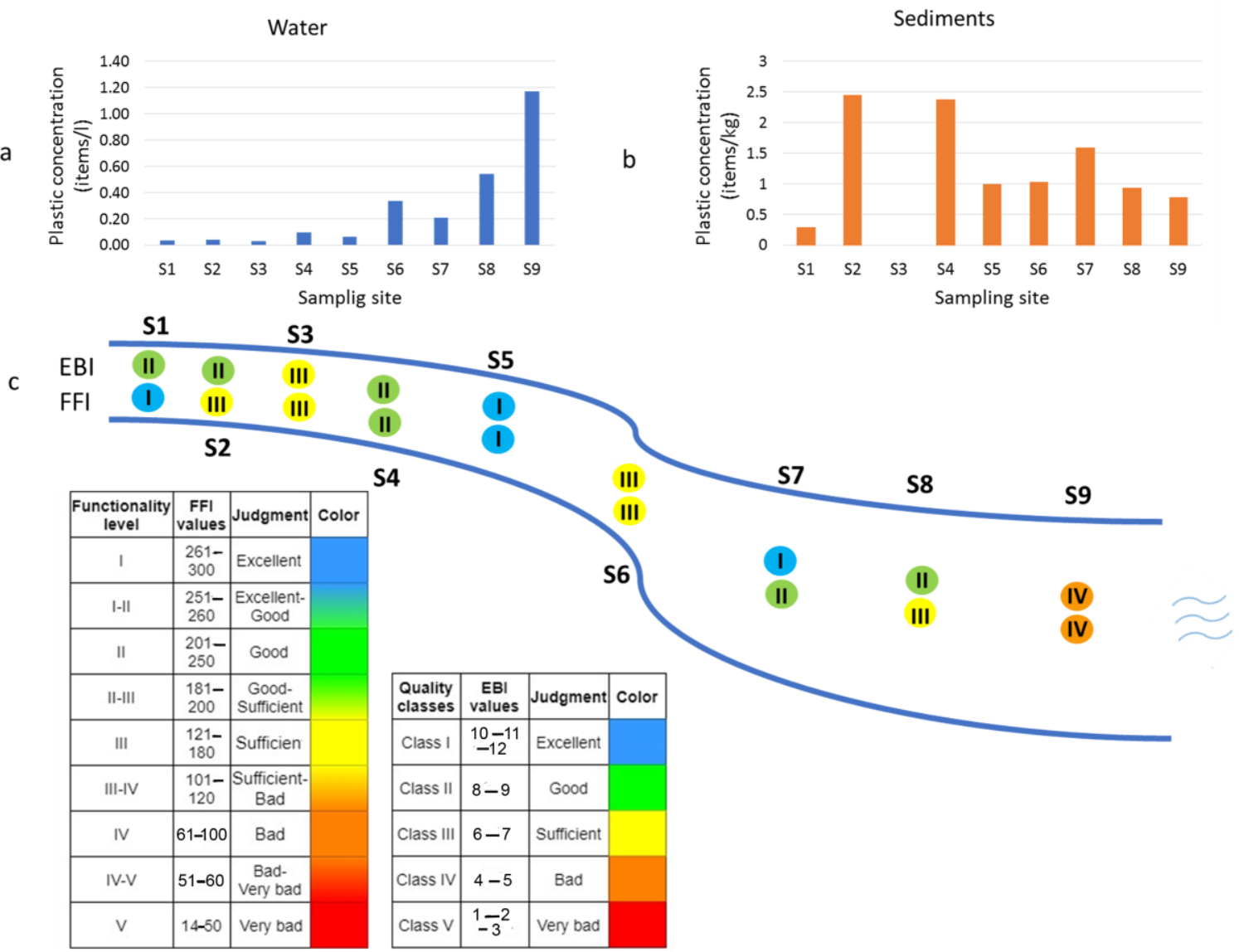

Figure 8. (a) Plastic concentration in water samples by station, (b) plastic concentration in sediment samples by station, (c) Extended Biotic Index (EBI) and Fluvial Functionality Index (FFI) results for each station by class and color (see the legends for details on the corresponding values and judgment). 

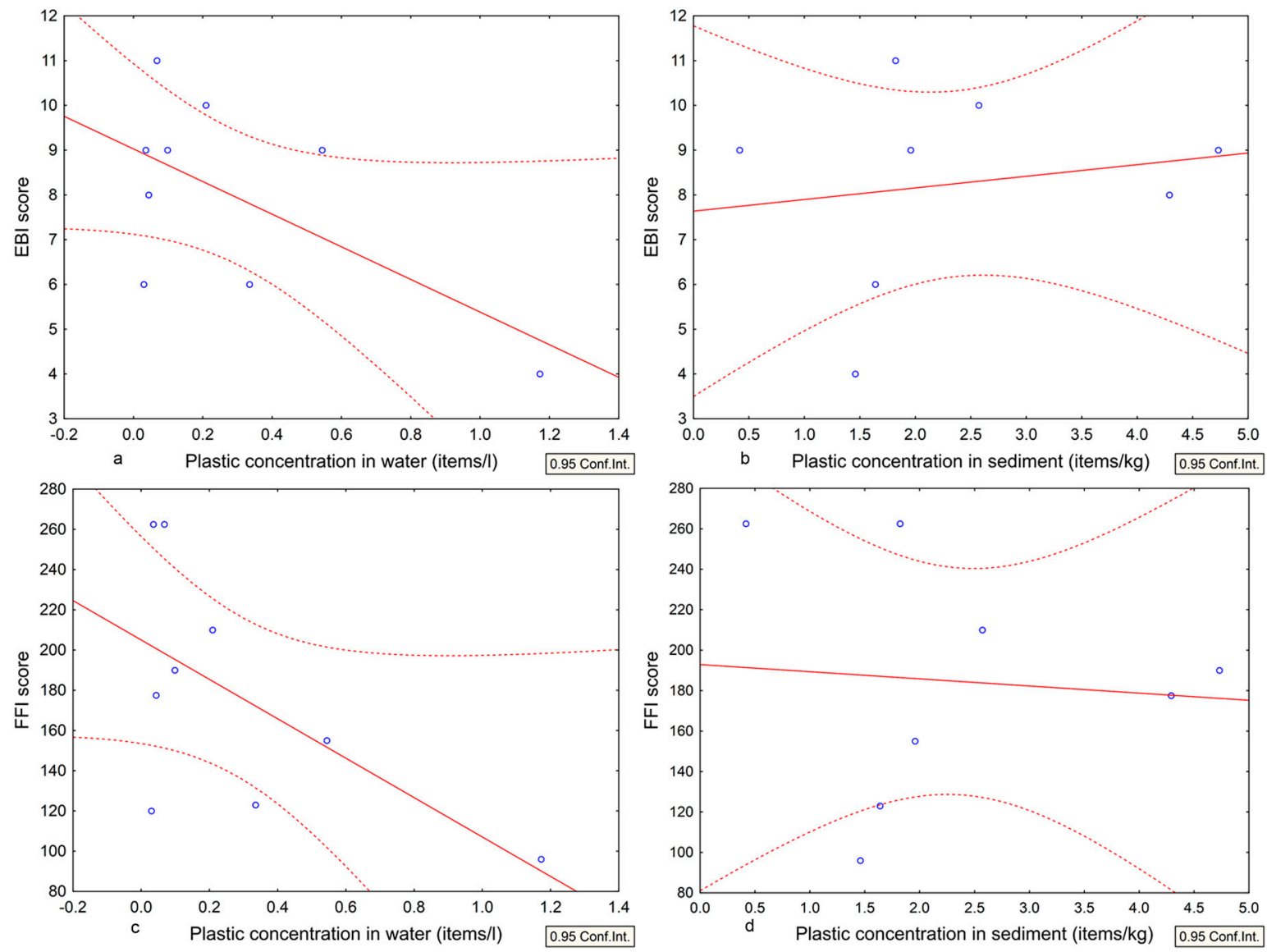

Figure 9. (a) Results of EBI compared to the concentration of plastics in water and (b) in sediments of each station, and (c) results of FFI compared to the concentration of plastics in water and (d) in sediments of each station.

\section{Discussion}

The present study analyzes the distribution of plastics along the River Mignone and contributes to fill the knowledge gap on plastic contamination of Mediterranean rivers recently highlighted in the scientific literature [46]. In fact, little information exists (Table 1). The comparison with existing papers shows that River Mignone is the least polluted by plastics for sediment samples and one of the most polluted for water among Mediterranean rivers (Table 1). It should be considered that only a few studies have been conducted on rivers flowing into the Mediterranean Sea (Table 1). For instance, the greater Mediterranean river, the River Nile, has not been sampled until now. Moreover, the mean concentration of plastic from the current study was 280 items $\mathrm{m}^{-3}$. This concentration is lower than the contamination mean value, as the global plastic concentration mean in water is 11,128 items $\mathrm{m}^{-3}$, as shown in the Introduction Section [4]. This could be due to the fact that River Mignone is characterized by low anthropic impacts and its course flows within a protected area, resulting in a generally well-preserved water and ecosystem quality. It should also be considered that it is located near towns poorly populated, as proximity to high human density areas is a factor influencing positively plastic discharge into freshwaters [47]. In particular, the higher and medium course of the river has low water contamination, which increases towards the mouth of the river. This could be due to the fact that plastic pollution accumulates in water as the river flows downstream by collecting inputs from the surrounding landscape and tributaries.

A further consideration on the sampling method regards the fact that the use of flow rate or velocity does not provide all relevant information on the hydromorphological characteristics of the sampled site. Indeed, equal flow rates could be provided by very different rivers with regards to 
hydromorphological factors, such as river depth and width. In this respect, we suggest including the previously described hydromorphological information on rivers during future samplings to allow the comparison of data from similar rivers. Also, standardized guidelines for monitoring rivers are suggested to take into account the natural diversity of hydromorphological factors.

Even though River Mignone is well preserved, the input of plastic caused by rivers that flow into the Mediterranean is considered relevant as rivers represent the major source and pathways of plastic transport to the sea [13]. As only a few studies [48,49] and models [13] investigated the plastic outputs from rivers into the Mediterranean Sea, further research is needed to fill this gap. In this regard, studies on the concentration and distribution of plastic along the entire river courses might contribute to better understand the health of the Mediterranean Sea. Particularly, which rivers are most contaminated and cause the most plastic release into the Mediterranean Sea.

A detailed analysis of plastic types highlighted that fibers were the most abundant in River Mignone, followed by fragments and films. Considering that fibers are a major contaminant globally [50], monitoring the distribution of fibers in nature provides information on the location of threat hotspots to the riverine ecosystem. In River Mignone, fibers accumulate mainly in S4 station (Supplementary Table S1), that is the most polluted by plastics. Near S4 station, there is an urban sewage [29] and a wastewater treatment plant that could be the cause of this pollution, as the latter are considered one of the main sources of plastics in aquatic ecosystems [15]. Especially, fibers occur more in sites close to wastewater treatment plants [14]. A potential source could be the release of plastic fibers from domestic washing machines [16].

The concentration of plastics along a river could also be affected by natural factors [51,52]. The result of grain size and plastic size analysis suggests that the spatial distribution of plastics in water and in sediment was related to riverine flow energy and follows the sedimentation process. The sinking of plastics in sediment could also explain the greater concentration found in sediments rather than in water of the River Mignone. Sediments can act as reservoir of plastics, however flooding periods can remobilize plastics, raising their bioavailability $[12,23]$. Therefore, the analysis of grain size could be further developed as an environmental indicator of potential accumulation sites of plastic items. This could be a useful tool for predicting the most sensitive areas to contamination and then to act for plastic removal. This information could be used for remediation activities, as this result suggests that the creation of low-energy flow areas could enhance the sinking of plastics with a certain amount of selectivity according to the plastic particle size and flow. The suitability of this remediation activity is to be tested. Moreover, since the actual classification of plastics is limited because it is not standardized and thus does not allow a versatile comparison, it was suggested that a universal classification of plastic could be based on grain size reference scale [53].

Concerning plastic in biota, here, we discussed the first occurrence of plastic in Hydroptilidae and Bereidae caddisfly cases. As for the comparison of plastic shapes, Hydroptilidae and Bereidae used only fibers, of which the majority were blue. A species of Odontoceridae, Odontocerum albicorne, used more fibers than films and fragments in its case [39], while a species of Lepidostomatidae, Lepidostoma basale, showed the opposite pattern [38]. Plastic shapes found in cases are suggested to depend on the environmental bioavailability of the sites inhabited by caddisflies [37]. The prevalence of plastic fibers is also assessed in other freshwater and marine species, e.g., fish and shrimps [54,55]. Indeed, fibers are generally the most abundant plastic shape contaminating freshwater [56], supporting the hypothesis that the environmental availability influences biota contamination. Regarding plastic colors, blue is the most abundant also in L. basale [38] and in O. albicorne [39]. It could be a preference of caddisflies for this color or rather its environmental bioavailability. In scientific literature, blue fibers are found in biota and they could be among the most abundant colors $[57,58]$, however, the abundance of plastics by color is poorly reviewed. In this work, blue is the main plastic color detected in waters, while sediments have a prevalence of white. This could suggest that the environmental matrix also plays a role in influencing the bioavailability of plastics to macroinvertebrates, meaning that contamination of water rather than sediment could have more of an effect on the type of plastics used by caddisflies for case 
construction. Further research is needed to investigate more deeply the factors that determine the finding in cases of certain shapes and colors of plastics.

The water quality assessment was evaluated with macroinvertebrates through the EBI, but it was not correlated with the plastics' concentration at each station. Therefore, it seems that EBI was not affected by the levels of plastics occurring in river as it is not a good proxy. Although water river quality was generally good, plastic items occurred in caddisfly cases. Thus, plastic concentration values are at such a level that the macroinvertebrate community is probably exposed but not affected. For instance, at the S4 station, where a high number of plastics occurred, the EBI score was high and the water river quality was in excellent status. Similarly, plastic concentration and FFI were not correlated, thus the river functionality was not affected by plastic concentration in situ, indicating a good quality of the River Mignone. This suggests that target investigations should be conducted to discriminate the exposure from the actual risk posed by the presence of plastics to biota and ecosystem.

\section{Conclusions}

This work has contributed to expand the research on distribution and monitoring of plastic along a Mediterranean river. In this study, we highlighted the occurrence of a plastic ecological gradient along the entire river course and the exploitation of EBI and IFF indices to evaluate plastic concentration. However, the plastic distribution does not seem to follow the riverine zonation of the River Continuum Concept, but the distance from the source affects the contamination of water. In addition, EBI and FFI cannot be exploited as proxies of plastic contamination of rivers. As the examined indices do not provide information on plastic pollution, the development of new standard and proficient monitoring tools is urgent for a quick and cost-effective assessment of freshwater ecosystems.

Results suggested that plastic concentration in water and in sediment are generally low if compared to other Mediterranean rivers (except for the riverine mouth in water) and that fibers are the main plastic type, considering wastewater treatment plants and washing machine release as their major source. However, in order to compare different levels of plastic pollution in environmental matrices, the use of different tools for sampling plastic (e.g., manta, plankton net, etc.) affect the size of the sampled plastic. Indeed, the absence of a standardized method encourages the use of different sampling methods, such as the newly developed Albatross Mark [59]. Therefore, the width of collected plastics varies due to the tool used for sampling. In this regard, there are several uncertainties in comparing the results we obtained with the scientific literature as the methods used are not adequate and not universal. For this reason, the creation of standardized guidelines is a matter of priority.

Further investigations are mandatory to increase the knowledge on distribution and monitoring of plastic along rivers. As an analysis gap in the literature, a modeling of the accumulation of microplastics in freshwater could be of relevant importance for freshwater ecosystem monitoring. In conclusion, biotic indices could be revised in order to be used as useful proxies of plastic in rivers.

Supplementary Materials: The following are available online at http://www.mdpi.com/2306-5338/7/4/90/s1, Figure S1: Images of the equipment used for this study, Figure S2: Spectra of most abundant plastics detected (PE and PP), Table S1: dataset of plastic occurrence in water, sediments and biota of River Mignone, Table S2: Results of grain size analysis by station.

Author Contributions: Conceptualization, L.G. and M.S. (Massimiliano Scalici); methodology, L.G., M.S. (Maria Sighicelli) and M.S. (Massimiliano Scalici); validation, L.G.; formal analysis, L.G., G.C., A.C., F.L. and P.M.; investigation, L.G.; resources, M.S. (Massimiliano Scalici), M.S. (Maria Sighicelli), P.M. and F.L.; data curation, L.G.; writing - original draft preparation, L.G., A.C. and G.C.; writing-review and editing, L.G., A.C., G.C. and M.S. (Massimiliano Scalici); visualization, L.G., G.C. and A.C.; supervision, M.S. (Massimiliano Scalici) and M.S. (Maria Sighicelli); project administration, M.S. (Massimiliano Scalici); funding acquisition, M.S. (Massimiliano Scalici). All authors have read and agreed to the published version of the manuscript.

Funding: This investigation was supported by funds from the Ministry of Education, University and Research for the base research individual activities, and by the Grant of Excellence Departments, MIUR-Italy (ARTICOLO 1, COMMI 314-337 LEGGE 232/2016).

Acknowledgments: The authors would like to acknowledge the ENEA Casaccia Research Center, in particular Loris Pietrelli, for his valuable contribution. 
Conflicts of Interest: The authors declare no conflict of interest.

\section{References}

1. de Sá, L.C.; Oliveira, M.; Ribeiro, F.; Rocha, T.L.; Futter, M.N. Studies of the effects of microplastics on aquatic organisms: What do we know and where should we focus our efforts in the future? Sci. Total Environ. 2018, 645, 1029-1039. [CrossRef] [PubMed]

2. Strungaru, S.-A.; Jijie, R.; Nicoara, M.; Plavan, G.; Faggio, C. Micro- (nano) plastics in freshwater ecosystems: Abundance, toxicological impact and quantification methodology. TrAC. Trend. Anal. Chem. 2019, 110, 116-128. [CrossRef]

3. Siegfried, M.; Koelmans, A.A.; Besseling, E.; Kroeze, C. Export of microplastics from land to sea. A modelling approach. Water Res. 2017, 127, 249-257. [CrossRef] [PubMed]

4. Cera, A.; Cesarini, G.; Scalici, M. Microplastics in freshwater: What are the news from the world? Diversity 2020, 12, 276. [CrossRef]

5. Atwood, E.C.; Falcieri, F.M.; Piehl, S.; Bochow, M.; Matthies, M.; Franke, J.; Carniel, F.; Sclavo, M.; Laforsch, C.; Siegert, F. Coastal accumulation of microplastic particles emitted from the Po River, Northern Italy: Comparing remote sensing and hydrodynamic modeling with in situ sample collections. Mar. Pollut. Bull. 2019, 138, 561-574. [CrossRef] [PubMed]

6. Campanale, C.; Stock, F.; Massarelli, C.; Kochleus, C.; Bagnuolo, G.; Reifferscheid, G.; Uricchio, V.F. Microplastics and their possible sources: The example of Ofanto River in southeast Italy. Environ. Pollut. 2020, 258, 113284. [CrossRef]

7. Constant, M.; Ludwig, W.; Kerhervé, P.; Sola, J.; Charrière, B.; Sanchez-Vidal, A.; Canals, M.; Heussner, S. Microplastic fluxes in a large and a small Mediterranean river catchments: The Têt and the Rhône, Northwestern Mediterranean Sea. Sci. Total Environ. 2020, 716, 136984. [CrossRef]

8. Simon-Sánchez, L.; Grelaud, M.; Garcia-Orellana, J.; Ziveri, P. River deltas as hotspots of microplastic accumulation: The case study of the Ebro River (NW Mediterranean). Sci. Total Environ. 2019, 687, 1186-1196. [CrossRef]

9. Blašković, A.; Guerranti, C.; Fastelli, P.; Anselmi, S.; Renzi, M. Plastic levels in sediments closed to Cecina river estuary (Tuscany, Italy). Mar. Pollut. Bull. 2018, 135, 105-109. [CrossRef]

10. Guerranti, C.; Cannas, S.; Scopetani, C.; Fastelli, P.; Cincinelli, A.; Renzi, M. Plastic litter in aquatic environments of Maremma Regional Park (Tyrrhenian Sea, Italy): Contribution by the Ombrone river and levels in marine sediments. Mar. Pollut. Bull. 2017, 117, 366-370. [CrossRef]

11. Eerkes-Medrano, D.; Thompson., R. Occurrence, fate, and effect of microplastics in freshwater systems. In Microplastic Contamination in Aquatic Environments; Zeng, E.Y., Ed.; Elsevier: Amsterdam, The Netherlands, 2018; pp. 95-132.

12. Besseling, E.; Quik, J.T.K.; Sun, M.; Koelmans, A.A. Fate of nano- and microplastics in freshwater systems: A modeling study. Environ. Pollut. 2017, 220, 540-548. [CrossRef] [PubMed]

13. Lebreton, L.C.M.; van der Zwet, J.; Damsteeg, J.-W.; Slat, B.; Andrady, A.; Reisser, J. River plastic emissions to the world's oceans. Nat. Commun. 2017, 8, 15611. [CrossRef] [PubMed]

14. McCormick, A.R.; Hoellein, T.J.; Mason, S.A.; Schluep, J.; Kelly, J.J. Microplastic is an abundant and distinct microbial habitat in an urban river. Environ. Sci. Technol. 2014, 48, 11863-11871. [CrossRef] [PubMed]

15. Murphy, F.; Ewins, C.; Carbonnier, F.; Quinn, B. Wastewater treatment works (WwTW) as a source of microplastics in the aquatic environment. Environ. Sci. Technol. 2016, 50, 5800-5808. [CrossRef] [PubMed]

16. Napper, I.E.; Thompson, R.C. Release of synthetic microplastic plastic fibres from domestic washing machines: Effects of fabric type and washing conditions. Mar. Pollut. Bull. 2016, 112, 39-45. [CrossRef]

17. Browne, M.A.; Crump, P.; Niven, S.J.; Teuten, E.; Tonkin, A.; Galloway, T.; Thompson, R. Accumulation of microplastic on shorelines worldwide: Sources and sinks. Environ. Sci. Technol. 2011, 45, 9175-9179. [CrossRef]

18. Dris, R.; Imhof, H.; Sanchez, W.; Gasperi, J.; Galgani, F.; Tassin, B.; Laforsch, C. Beyond the ocean: Contamination of freshwater ecosystems with (micro-)plastic particles. Environ. Chem. 2015, 12, 539-550. [CrossRef]

19. Zhang, K.; Chen, X.; Xiong, X.; Ruan, Y.; Zhou, H.; Wu, C.; Lam, P.K.S. The hydro-fluctuation belt of the Three Gorges Reservoir: Source or sink of microplastics in the water? Environ. Pollut. 2019, 248, $279-285$. [CrossRef] [PubMed]

20. Waldschläger, K.; Schüttrumpf, H. Erosion behavior of different microplastic particles in comparison to natural sediments. Environ. Sci. Technol. 2019, 53, 13219-13227. [CrossRef] 
21. Hoellein, T.J.; Shogren, A.J.; Tank, J.L.; Risteca, P.; Kelly, J.J. Microplastic deposition velocity in streams follows patterns for naturally occurring allochthonous particles. Sci. Rep. 2019, 9, 3740. [CrossRef]

22. Hurley, R.; Woodward, J.; Rothwell, J.J. Microplastic contamination of river beds significantly reduced by catchment-wide flooding. Nat. Geosci. 2018, 11, 251-257. [CrossRef]

23. Ockelford, A.; Cundy, A.; Ebdon, J.E. Storm response of fluvial sedimentary microplastics. Sci. Rep. 2020, 10, 1865. [CrossRef] [PubMed]

24. European Commission. Directive 2000/60/EC of the European Parliament and of the Council of 23 October 2000 establishing a framework for Community action in the field of water policy. Off. J. Eur. Communities Legis. 2000, 327, 1-73.

25. Nel, H.A.; Dalu, T.; Wasserman, R.J. Sinks and sources: Assessing microplastic abundance in river sediment and deposit feeders in an Austral temperate urban river system. Sci. Total Environ. 2018, 612, 950-956. [CrossRef] [PubMed]

26. Ehlers, S.M.; Al Najjar, T.; Taupp, T.; Koop, J.H.E. PVC and PET microplastics in caddisfly (Lepidostoma basale) cases reduce case stability. Environ. Sci. Pollut. Res. 2020, 27, 22380-22389. [CrossRef]

27. Ghetti, P.F.; The Extended Biotic Index (EBI). Macroinvertebrates in the Quality Control of Freshwater Environments; Provincia Autonoma di Trento: Trento, Italy, 2017; (Italian).

28. Siligardi, M.; Avolio, F.; Baldaccini, G.; Bernabei, S.; Bucci, M.S.; Cappelletti, C.; Chierici, E.; Ciutti, F.; Sansoni, G.; Floris, B.; et al. Indice di Funzionalità Fluviale I.F.F.; APAT: Roma, Italy, 2007.

29. Morgana, J.G.; Prato, S.; Antonelli, D. Caratterizzazione della Qualità Ambientale del Fiume Mignone Tramite il Calcolo di Indici Biotici Basati sulla Struttura delle Comunità di Macroinvertebrati Bentonici; ENEA-Dipartimento Ambiente Centro Ricerche Casaccia: Roma, Italy, 1999.

30. Remote Sensing Project. Available online: http://www.pcn.minambiente.it/mattm/progetto-pianostraordinario-di-telerilevamento/ (accessed on 4 September 2020). (Italian).

31. Traversetti, L.; Scalici, M. Assessing the influence of source distance and hydroecoregion on the invertebrate assemblage similarity in central Italy streams. Knowl. Manag. Aquat. Ecosyst. 2014, 414, 2. [CrossRef]

32. Tachet, H.; Richoux, P.; Bournaud, M.; Usseglio-Polatera, P. Invertébrés D'eau Douce: Systématique, Biologie, Écologie; CNRS editions: Paris, France, 2010; Volume 15.

33. Nuelle, M.T.; Dekiff, J.H.; Remy, D.; Fries, E. A new analytical approach for monitoring microplastics in marine sediments. Environ. Pollut. 2014, 184, 161-169. [CrossRef]

34. Blair, R.M.; Waldron, S.; Phoenix, V.R.; Gauchotte-Lindsay, C. Microscopy and elemental analysis characterisation of microplastics in sediment of a freshwater urban river in Scotland, UK. Environ. Sci. Pollut. Res. 2019, 26, 12491-12504. [CrossRef]

35. Folk, R.L. The distinction between grain size and mineral composition in sedimentary-rock nomenclature. J. Geol. 1954, 62, 344-359. [CrossRef]

36. Folk, R.L. Petrology of Sedimentary Rocks; Hemphill Publishing Co.: Austin, TX, USA, 1974; p. 182.

37. Tibbetts, J.; Krause, S.; Lynch, I.; Smith, G.H.S. Abundance, distribution, and drivers of microplastic contamination in urban river environments. Water 2018, 10, 1597. [CrossRef]

38. Ehlers, S.M.; Manz, W.; Koop, J.H.E. Microplastics of different characteristics are incorporated into the larval cases of the freshwater caddisfly Lepidostoma Basale. Aquat. Biol. 2019, 28, 67-77. [CrossRef]

39. Gallitelli, L.; Cera, A.; Cesarini, G.; Pietrelli, L.; Scalici, M. Microplastics effects on macroinvertebrates: Preliminary indoor evidences on case making caddisflies and burrowing mayflies. (unpublished; manuscript in preparation).

40. Hidalgo-Ruz, V.; Gutow, L.; Thompson, R.C.; Thiel, M. Microplastics in the marine environment: A review of the methods used for identification and quantification. Environ. Sci. Technol. 2012, 46, 3060-3075. [CrossRef] [PubMed]

41. Su, L.; Xue, Y.; Li, L.; Yang, D.; Kolandhasamy, P.; Li, D.; Shi, H. Microplastics in Taihu Lake, China. Environ. Pollut. 2016, 216, 711-719. [CrossRef] [PubMed]

42. Su, L.; Cai, H.; Kolandhasamy, P.; Wu, C.; Rochman, C.M.; Shi, H. Using the Asian clam as an indicator of microplastic pollution in freshwater ecosystems. Environ. Pollut. 2018, 234, 347-355. [CrossRef] [PubMed]

43. Tancioni, L.; Celauro, D.; Colombari, P.T.; Gibertini, G.; Maio, G.; Sarrocco, S.; Scalici, M. La carta della biodiversità ittica del Lazio: Analisi preliminare dei risultati. Ital. J. Freshwater Ichthyol. 2017, 1. Available online: http://www.aiiad.it/ijfi/index.php/ijfi/article/view/14 (accessed on 1 September 2020).

44. Vannote, R.L.; Minshall, G.W.; Cummins, K.W.; Sedell, J.R.; Cushing, C.E. The River Continuum Concept. Can. J. Fish Aquat. Sci. 1980, 37, 130-137. [CrossRef] 
45. Illies, J.; Botosaneanu, L. Problèmes et méthodes de la classification et de la zonation écologique des eaux courantes, considerées surtout du point de vue faunistique. Mitt. Int. Ver. Theor. Angew. Limnol. 1963, 12, 1-57. [CrossRef]

46. Guerranti, C.; Perra, G.; Martellini, T.; Giari, L.; Cincinelli, A. Knowledge about microplastics in Mediterranean tributary river ecosystems: Lack of data and research needs on such a crucial marine pollution source. J. Mar. Sci. Eng. 2020, 8, 216. [CrossRef]

47. Kataoka, T.; Nihei, Y.; Kudou, K.; Hinata, H. Assessment of the sources and inflow processes of microplastics in the river environments of Japan. Environ. Pollut. 2019, 244, 958-965. [CrossRef]

48. Faure, F.; Demars, C.; Wieser, O.; Kunz, M.; de Alencastro, L.F. Plastic pollution in Swiss surface waters: Nature and concentrations, interaction with pollutants. Environ. Chem. 2015, 12, 582-591. [CrossRef]

49. Schmidt, L.K.; Bochow, M.; Imhof, H.K.; Oswald, S.E. Multi-temporal surveys for microplastic particles enabled by a novel and fast application of SWIR imaging spectroscopy-Study of an urban watercourse traversing the city of Berlin, Germany. Environ. Pollut. 2018, 239, 579-589. [CrossRef] [PubMed]

50. Li, C.; Busquets, R.; Campos, L.C. Assessment of microplastics in freshwater systems: A review. Sci. Total Environ. 2020, 707, 135578. [CrossRef] [PubMed]

51. Corcoran, P.L.; Belontz, S.L.; Ryan, K.; Walzac, M.J. Factors controlling the distribution of miroplastic particles in benthic sediment of the Thames River, Canada. Environ. Sci. Technol. 2020, 54, 818-825. [CrossRef] [PubMed]

52. Falahudin, D.; Cordova, M.R.; Sun, X.; Yogaswara, D.; Wulandari, I.; Hindarti, D.; Arifin, Z. The first occurrence, spatial distribution and characteristics of microplastic particles in sediments from Banten Bay, Indonesia. Sci. Total Environ. 2020, 705, 135304. [CrossRef] [PubMed]

53. Kedzierski, M.; Le Tilly, V.; Bourseau, P.; Bellegou, H.; César, G.; Sire, O.; Bruzaud, F. Microplastics elutriation for sandy sediments: A granulometric approach. Mar. Pollut. Bull. 2016, 107, 315-323. [CrossRef] [PubMed]

54. Zhang, L.; Xie, Y.; Zhong, S.; Liu, J.; Qin, Y.; Gao, P. Microplastics in freshwater and wild fishes from Lijiang River in Guangxi, Southwest China. Sci. Total Environ. 2021, 755, 142428. [CrossRef]

55. Fernández Severini, M.D.; Buzzi, N.S.; Forero López, A.D.; Colombo, C.V.; Chatelain Sartor, G.L.; Rimondino, G.N.; Truchet, D.M. Chemical composition and abundance of microplastics in the muscle of commercial shrimp Pleoticus muelleri at an impacted coastal environment (Southwest Atlantic). Mar. Pollut. Bull. 2020, 161, 111700. [CrossRef]

56. Shahul Hamid, F.; Sanam Bhatti, M.; Anuar, N.; Mohan, P.; Periathamby, A. Worldwide distribution and abundance of microplastic: How dire is the situation? Waste Manag. Res. 2018, 36, 873-897. [CrossRef]

57. Nguyen, Q.A.T.; Nguyen, H.N.Y.; Strady, E.; Nguyen, Q.T.; Trinh-Dang, M. Characteristics of microplastics in shoreline sediments from a tropical and urbanized beach (Da Nang, Vietnam). Mar. Pollut. Bull. 2020, 161, 111768. [CrossRef]

58. Neto, J.G.B.; Rodriguez, F.L.; Ortega, I.; dos S. Rodrigues, L.; Lacerda, A.L.d.F.; Coletto, J.L.; Kessler, F.; Cardoso, L.G.; Madureira, L.; Proietti, M.C. Ingestion of plastic debris by commercially important marine fish in southeast-south Brazil. Environ. Pollut. 2020, 267, 115508. [CrossRef]

59. Abeynayaka, A.; Kojima, F.; Miwa, Y.; Ito, N.; Nihei, Y.; Fukunaga, Y.; Yashima, Y.; Itsubo, N. Rapid sampling of suspended and floating microplastics in challenging riverine and coastal water environments in Japan. Water 2020, 12, 1903. [CrossRef]

Publisher's Note: MDPI stays neutral with regard to jurisdictional claims in published maps and institutional affiliations.

(C) 2020 by the authors. Licensee MDPI, Basel, Switzerland. This article is an open access article distributed under the terms and conditions of the Creative Commons Attribution (CC BY) license (http://creativecommons.org/licenses/by/4.0/). 